\title{
Sensitisation to enzymes in the animal feed industry
}

\author{
M Vanhanen, T Tuomi, U Tiikkainen, O Tupasela, A Tuomainen, R Luukkonen, \\ H Nordman
}

\begin{abstract}
Objectives-To assess the prevalence of enzyme sensitisation in the animal feed industry.

Methods-A cross sectional study was conducted in four animal feed factories, where several enzymes had been used in powder form for 7-9 years. Before this study, enzymes in liquid form had started to be used. Sensitisation to enzymes was examined by skin prick and radioallergosorbent (RAST) tests. Altogether 218 workers were tested; 140 people in various tasks in manufacturing, where exposure to various organic dusts and to enzymes was possible, and 78 non-exposed office workers. The workers were interviewed for work related respiratory and skin symptoms. Total dust concentrations were measured by a gravimetric method. The concentrations of protease and $\alpha$-amylase were measured with catalytic methods and that of xylanase with an immunological method.
\end{abstract}

Results-Ten workers (7\%) were sensitised to enzymes in the exposed group of 140 , whereas none were sensitised in the non-exposed group. Six of the sensitised people had respiratory symptoms at work: two of them especially in connection with exposure to enzymes. Enzyme concentrations in the air varied greatly: xylanase from less than $0.8 \mathrm{ng} / \mathrm{m}^{3}$ up to $16 \mathrm{ng} / \mathrm{m}^{3}$, $\alpha$-amylase from less than $20 \mathrm{ng} / \mathrm{m}^{3}$ up to $200 \mathrm{ng} / \mathrm{m}^{3}$, and protease from less than 0.4 $\mathrm{ng} / \mathrm{m}^{3}$ up to $2900 \mathrm{ng} / \mathrm{m}^{3}$. On average, highest xylanase and $\alpha$-amylase concentrations were found in the various manufacturing sites, whereas the highest protease concentrations were found in areas of high total dust.

Conclusions-Industrial enzymes may cause allergies in the animal feed industry. There is a need to assess exposure to enzymes at various phases of production, and to minimise exposures.

(Occup Environ Med 2001;58:119-123)

Keywords: animal feed; enzyme allergy; occupational exposure

Kuopio Regional

Institute of

Occupational Health,

PO Box 93, FIN-70701, Kuopio, Finland

A Tuomainen

Correspondence to:

Dr M Vanhanen

markku.vanhanen@

occuphealth.fi

Accepted 19 October 2000
Enzyme allergy has been recognised since With and is now common in many industries.-5 digestion of the feed can be improved especially in monogastric animals, such as poultry and pigs. The different enzymes used include cellulases, hemicellulases, $\beta$-glucanases, pro- teases, phytases, glucoamylases, and $\alpha$-amylases. The manufacturing of animal feed comprises large scale milling and mixing of the components, followed by pelleting and packing of the products. The main component is grain, mainly barley which comprises about $60 \%$ of the ingredients. Other examples of components are soy, rape, byproducts from the food, brewing, and sweetener industries (molasses, mash), and vitamins and minerals. The processes are largely closed ones; strict precautions are needed from the hygiene point of view to prevent microbial contamination. Until now the enzymes have been incorporated into the feed as premixes in powder or granule form, containing $0.1 \%-1 \%$ enzyme. Exposure to enzymes occurs during filling of the silos with enzymes. Disturbances and leaks in the production lines may result in release of enzyme dust into the factory air. Liquid enzymes have been introduced in recent years.

The allergenic potential of the enzymes used in the animal feed industry has been proved in other industries. ${ }^{3}$ Before our study, one case of rhinitis induced by cellulase in an animal feed factory was diagnosed by us at the Finnish Institute of Occupational Health in 1992 (Finnish Register of Occupational Diseases). Phytase, which has been developed solely for use in animal feed, was first shown to cause allergy in enzyme production by Vanhanen et al. ${ }^{6}$ Recently, Doekes et al reported allergic sensitisation to phytase as a probable cause of work related asthmatic symptoms in a factory where animal feed additives were produced. The aim of our study was to assess the exposure to dusts and enzymes as well as the prevalence of enzyme sensitisation in this industry.

\section{Subjects and methods}

The study was carried out in four animal feed factories in 1996. All the factories were owned by the same industrial company. The total annual production in the four factories was about 800000 tonnes of animal feed. Production methods and enzymes in use in respective factories were similar. Dry premixed enzymes in powdered or granule form had been used for 7-9 years. Changes in the addition of enzymes have been made recently, a few months before our study. The new technique uses liquid enzymes that are sprayed on the feed granules or pellets in a closed spraying tower.

All employees were invited to the tests; the participation rate was $97 \%$. Altogether, 218 employees were tested; 140 of them were engaged in process work and 78 in office work. 
Table 1 Sex, age, duration of employment in animal feed industry, and smoking

\begin{tabular}{|c|c|c|c|c|c|c|c|c|}
\hline \multirow{2}{*}{$\begin{array}{l}\text { Workplace } \\
\text { (people tested) }\end{array}$} & \multicolumn{2}{|c|}{$\operatorname{Sex}$} & \multicolumn{2}{|l|}{ Age } & \multicolumn{2}{|c|}{$\begin{array}{l}\text { Duration of employment } \\
\text { in animal feed industry }\end{array}$} & \multicolumn{2}{|c|}{ Smoking } \\
\hline & $F$ & $M$ & Mean & Range & $\leqslant 10 y$ & $>10 y$ & $n$ & $\%$ \\
\hline \multicolumn{9}{|l|}{ Factory $1(n=37)$ : } \\
\hline Process $(n=26)$ & 2 & 24 & 44.0 & $23-59$ & 8 & 18 & 10 & 38 \\
\hline Office $(n=11)$ & 7 & 4 & 43.6 & $30-57$ & 2 & 9 & 5 & 45 \\
\hline \multicolumn{9}{|l|}{ Factory $2(n=49)$ : } \\
\hline Process $(n=33)$ & 1 & 32 & 42.5 & $29-59$ & 7 & 26 & 13 & 39 \\
\hline Office $(n=16)$ & 8 & 8 & 37.8 & $23-56$ & 8 & 8 & 5 & 31 \\
\hline \multicolumn{9}{|l|}{ Factory $3(n=79)$ : } \\
\hline Process $(n=43)$ & 12 & 31 & 40.7 & $21-58$ & 19 & 24 & 17 & 39 \\
\hline Office $(n=36)$ & 12 & 24 & 41.5 & $28-59$ & 20 & 16 & 11 & 31 \\
\hline \multicolumn{9}{|l|}{ Factory $4(n=53)$ : } \\
\hline Process $(n=38)$ & 4 & 34 & 45.9 & $22-60$ & 10 & 24 & 14 & 37 \\
\hline Office $(n=15)$ & 5 & 10 & 43.8 & $33-58$ & 6 & 4 & 4 & 27 \\
\hline
\end{tabular}

The office workers were assumed not to be exposed during their work to the sensitising substances of the process-such as grain dust and enzymes. Detailed data of the employees' age, sex, and work history are given in table 1 .

QUESTIONNAIRE

The employees answered a questionnaire on work history, history of atopy, smoking habits, and work related symptoms that would indicate hypersensitivity. The questions were taken from the extensive Finnish Tuohilampiquestionnaire, developed by researchers from the Finnish Institute of Occupational Health, the National Public Health Institute and several universities. ${ }^{8}$ The Tuohilampi-questionnaire is based on several international established questionnaires.

SKIN PRICK TESTS

Atopy was assessed by skin prick tests with a panel of common environmental allergens: cat, dog, timothy, birch, alder, mugwort, house dust mite (Dermatophagoides pteronyssinus), and the moulds Alternaria, Cladosporium, Aspergillus fumigatus, and Aspergillus niger (Allergologisk Laboratorium A/S, ALK, Copenhagen, Denmark). Histamine hydrochloride $(10 \mathrm{mg} /$ $\mathrm{ml}$ ) was used as the positive control. A person with one or more positive skin prick test reactions to environmental allergens was defined as atopic. Also, the workers were tested with rye, wheat, barley, and oat flours. For the storage mite tests, Acarus siro, Lepidoglyphus destruens, and Tyrophagus putres (ALK) were used. To assess sensitisation to enzymes, skin prick tests were performed with enzyme preparations: a cellulase Novozyme (Novo Nordisk A/S, Denmark), a $\beta$-glucanase Multifect BGL (Genencor International, Finland), a xylanase GC 140 (Genencor), a protease Neutrase 0.5 (Novo), a protease Multifect P 3000 (Genencor), an $\alpha$-amylase BAN $480 \mathrm{~L}$ (Novo), a glucoamylase Spezyme GA 300 (Genencor), and a phytase Natuphos. The tests were performed at a protein concentration of 100 $\mu \mathrm{g} / \mathrm{ml}$. The test extracts were prepared, and the tests were performed as described by Vanhanen et al. ${ }^{5}$ In all tests, a weal of equal to or greater than $3 \mathrm{~mm}$ in diameter and equal to or greater than half of that of the histamine were defined as positive, indicating sensitisation.
IgE MEASUREMENTS

Specific IgE antibodies to enzymes were determined by the radioallergosorbent test (RAST). Proteins of commercial enzyme preparations were conjugated to cyanogen bromide activated paper discs with the method of Ceska et $a l .{ }^{9}$ Values over $0.35 \mathrm{kU} / 1$ were defined as positive, indicating sensitisation. The RAST tests were performed if a person reacted to one or more enzymes in the skin prick tests.

DUST MEASUREMENT

The samples for total dust measurement and for enzyme assay were collected by a standardised method in the breathing zone of the workers covering the work shift at a flow rate of 2 $1 / \mathrm{min}$ and by area sampling at a flow rate of 20 $1 / \mathrm{min}$, with $37 \mathrm{~mm}$ Millipore AA filters in an open face Millipore cassette for gravimetric measurement of the dust. Sampling times were about 4 hours in the breathing zone samples and $2-5$ hours in the area samples. The detection limit of this method is $0.1 \mathrm{mg} / \mathrm{m}^{3}$ for total dust.

MEASUREMENT OF ENZYMES

$\alpha$-Amylase was analysed colorimetrically with a commercial standard kit. ${ }^{10}$ The method gives the amount of active enzyme. The detection limit, which depends on sample volume, was $100 \mathrm{ng} / \mathrm{sample}$ corresponding to $20 \mathrm{ng} / \mathrm{m}^{3}$ in area samples and $200 \mathrm{ng} / \mathrm{m}^{3}$ in personal samples. Protease was measured with a catalytic method described by Vanhanen et al. ${ }^{11}$ The detection limit in area samples was 4 $\mathrm{ng} / \mathrm{m}^{3}$ and in personal samples $40 \mathrm{ng} / \mathrm{m}^{3}$. Xylanase was measured with an immunological method. The xylanase fractions pI 9.0 and pI 5.2, the two xylanases produced by Trichoderma reesei, were measured in this way. ${ }^{5}$ Only area sampling was used; the detection limit was 0.8 $\mathrm{ng} / \mathrm{m}^{3}$.

STATISTICAL ANALYSIS

The associations of work category, sensitisation, and symptoms were examined with logistic regression models. Odds ratios and their 95\% confidence intervals were calculated.

\section{Results}

SENSITISATION TO ENZYMES, FLOURS, AND STORAGE MITES

The results are summarised in table 2 . Ten people $(7 \%)$ in the process group were sensitised to enzymes. Six of them worked in different tasks in the processes: in granulation, bagging, and dosage of vitamins, minerals, and enzymes. One was a foreman, two were forklift truck drivers, and one was a maintenance man. Eight of them had been employed in the industry more than 10 years and two more than 5 but less than 10 years. The enzyme reactions were as follows: two reacted merely to the protease Multifect P 3000, the other eight reacted to several enzymes. Seven reacted to cellulase, xylanase, or $\beta$-glucanase, five to phytase, three to glucoamylase, and one to $\alpha$-amylase. Six of the enzyme positive workers also reacted to environmental allergens, and four to flours. 
Table 2 Atopy (by skin prick test) and skin prick test and radioallergosorbent test (RAST) results to enzymes, flours, and storage mites in the process and office workers

\begin{tabular}{|c|c|c|c|c|c|c|c|c|c|c|c|}
\hline & \multirow{2}{*}{\multicolumn{2}{|c|}{$\begin{array}{l}\text { Atopy by skin } \\
\text { prick test }\end{array}$}} & \multicolumn{3}{|c|}{ Sensitisation to enzymes } & \multicolumn{3}{|c|}{ Sensitisation to flours } & \multicolumn{3}{|c|}{ Sensitisation to storage mites } \\
\hline & & & \multicolumn{2}{|c|}{ Skin prick test } & \multirow{2}{*}{$\begin{array}{l}R A S T^{\star} \\
n\end{array}$} & \multicolumn{2}{|c|}{ Skin prick test } & \multirow{2}{*}{$\begin{array}{l}R A S T^{\star} \\
n\end{array}$} & \multicolumn{2}{|c|}{ Skin prick test } & \multirow{2}{*}{$\begin{array}{l}R A S T^{\star} \\
n\end{array}$} \\
\hline & $n$ & $\%$ & $n$ & $\%$ & & $n$ & $\%$ & & $n$ & $\%$ & \\
\hline Process workers $(n=140)$ & 33 & 24 & 10 & 7 & 3 & 7 & 5 & 6 & 26 & 19 & 9 \\
\hline Office workers $(\mathrm{n}=78)$ & 28 & 31 & 0 & & & 8 & 10 & 2 & 9 & 12 & 1 \\
\hline
\end{tabular}

^RAST performed if skin prick test positive.

The relation of atopy and work category to sensitisation to enzymes, flours, and storage mites is shown in table 3.

\section{SYMPTOMS AT WORK}

Work related rhinitis (stuffy nose or watery discharge) was twice as common among the process workers $(16 \%)$ as in the office personnel $(8 \%)$, whereas work related symptoms of the lower respiratory tract (recurrent cough, dyspnoea, or wheezing) were as common (4\%) in the process and in the office groups. During leisure time, upper respiratory or lower airway symptoms were reported twice as often by the office personnel as by the process personnel $(35 \% v 19 \%)$. The associations of work category, sensitisation, and symptoms are presented in table 4. Smoking was not associated with sensitisation to enzymes, flour, or storage mites, nor with work related symptoms.

Six of those sensitised to enzymes reported respiratory symptoms at work: mainly rhinitis in connection with exposure to dust. One

Table 3 Sensitisation to enzymes, flour, and storage mites relative to work category and atopy

\begin{tabular}{|c|c|c|c|c|c|c|}
\hline & \multicolumn{6}{|c|}{ Sensitisation by skin prick test } \\
\hline & \multicolumn{2}{|c|}{ Enzymes } & \multicolumn{2}{|c|}{ Flours } & \multicolumn{2}{|c|}{ Storage mites } \\
\hline & $O R$ & $95 \% C I$ & OR & $95 \% C I$ & $O R$ & $95 \% C I$ \\
\hline \multicolumn{7}{|l|}{ Unadjusted: } \\
\hline Atopy (prick test) & 4.2 & 1.1 to 15.3 & 46.5 & 6.0 to 362.7 & 8.6 & 3.9 to 19.2 \\
\hline Process work & $\star$ & & 0.6 & 0.2 to 1.9 & 2.1 & 0.9 to 4.9 \\
\hline \multicolumn{7}{|l|}{ Adjusted: } \\
\hline Atopy (prick test) & * & & 45.6 & 5.8 to 356.5 & 9.9 & 4.3 to 22.7 \\
\hline Process work & * & & 0.7 & 0.2 to 2.3 & 2.9 & 1.1 to 7.3 \\
\hline
\end{tabular}

${ }^{\star}$ Comparisons not done. Enzyme sensitisation occurred only in the process group.

Table 4 Associations between respiratory symptoms and sensitisation to enzymes, flours, storage mites, and environmental allergens (atopy), and work category

\begin{tabular}{|c|c|c|c|c|}
\hline \multirow[b]{3}{*}{ Sensitisation } & \multicolumn{4}{|c|}{ Symptoms at work } \\
\hline & \multicolumn{2}{|c|}{ Rhinitis* } & \multicolumn{2}{|c|}{$\begin{array}{l}\text { Lower respiratory tract } \\
\text { symptomst }\end{array}$} \\
\hline & $O R$ & $95 \% C I$ & $O R$ & $95 \% C I$ \\
\hline \multicolumn{5}{|l|}{ Enzymes: } \\
\hline Unadjusted & 4.7 & 1.2 to 17.6 & 8.4 & 1.5 to 48.4 \\
\hline Adjusted $\ddagger$ & 4.8 & 1.2 to 18.6 & 5.7 & 0.9 to 35.5 \\
\hline \multicolumn{5}{|l|}{ Flours: } \\
\hline Unadjusted & 1.6 & 0.4 to 6.2 & 9.9 & 2.1 to 46.4 \\
\hline Adjusted $\ddagger$ & 1.6 & 0.4 to 7.3 & 5.6 & 0.9 to 34.7 \\
\hline \multicolumn{5}{|l|}{ Storage mites: } \\
\hline Unadjusted & 1.1 & 0.4 to 3.0 & 0.7 & 0.1 to 6.2 \\
\hline Adjusted $\ddagger$ & 1.0 & 0.3 to 3.1 & 0.3 & 0.0 to 3.0 \\
\hline \multicolumn{5}{|c|}{ Atopy (skin prick test): } \\
\hline Unadjusted & 1.1 & 0.5 to 2.6 & 4.6 & 1.1 to 19.8 \\
\hline \multicolumn{5}{|l|}{ Process work: } \\
\hline Unadjusted & 3.2 & 1.2 to 8.7 & 0.9 & 0.2 to 4.0 \\
\hline Adjusted $\ddagger$ & 3.2 & 1.2 to 8.8 & 1.0 & 0.2 to 4.5 \\
\hline
\end{tabular}

*Stuffy nose or watery discharge.

tRecurrent cough, dyspnoea, or wheezing.

¥Adjusted for atopy (atopy by skin prick test). reported rhinitis and dyspnoea when handling enzyme premixes and flour. One reported dyspnoea especially when handling enzyme premixes; occupational asthma due to cellulase was diagnosed later with bronchial challenge tests.

AIR CONCENTRATIONS OF DUST AND ENZYMES

The concentrations of total dust, protease, xylanase, and $\alpha$-amylase are summarised in tables 5 and 6 . The total dust concentrations varied in area measurements between less than $0.1 \mathrm{mg} / \mathrm{m}^{3}$ to over $30 \mathrm{mg} / \mathrm{m}^{3}$. The enzyme concentrations also ranged widely. The highest concentrations of total dust were measured in grain receipt stations, in the loading of the feed into lorries, and in maintenance work: up to 38 $\mathrm{mg} / \mathrm{m}^{3}$ in area samples and up to $30 \mathrm{mg} / \mathrm{m}^{3}$ in personal samples. Protease concentrations up to $2900 \mathrm{ng} / \mathrm{m}^{3}$ in area samples and up to 360 $\mathrm{ng} / \mathrm{m}^{3}$ in personal samples were found in grain receipt stations. In tasks where enzyme premixes were handled, total dust concentration was on average $0.5 \mathrm{mg} / \mathrm{m}^{3}$, protease concentration was below the detection limit, and xylanase area sampling gave values of $0.7-$ $4.5 \mathrm{ng} / \mathrm{m}^{3}$. In tasks involving the process control, total dust concentration was $0.1-1.2$ $\mathrm{mg} / \mathrm{m}^{3}$ in personal samples, protease was below the detection limit. In granulating and other process work total dust was on average $0.1-3.1$ $\mathrm{mg} / \mathrm{m}^{3}$ in personal samples and up to $4.5-7.8$

Table 5 Concentrations of protease and xylanase in animal feed factories

\begin{tabular}{|c|c|c|c|c|c|}
\hline & \multirow{2}{*}{$\begin{array}{l}\text { Area }(A) \\
\text { and } \\
\text { personal } \\
(P) \\
\text { samples }\end{array}$} & \multirow[b]{2}{*}{$\begin{array}{l}\text { Samples } \\
(n)\end{array}$} & \multicolumn{3}{|c|}{ Concentration } \\
\hline & & & Mean & Median & Range \\
\hline \multicolumn{6}{|c|}{ Total dust $\left(\mathrm{mg} / \mathrm{m}^{3}\right)$ : } \\
\hline \multirow[t]{2}{*}{ Factory 1} & $\mathrm{~A}$ & 35 & 1.4 & 0.7 & $<0.1-7.9$ \\
\hline & $\mathrm{P}$ & 18 & 2.5 & 0.9 & $0.2-30$ \\
\hline \multirow[t]{2}{*}{ Factory 2} & A & 32 & 2.0 & 0.4 & $<0.1-34$ \\
\hline & $\mathrm{P}$ & 19 & 1.8 & 1.0 & $<0.1-6.1$ \\
\hline \multirow[t]{2}{*}{ Factory 3} & A & 34 & 1.0 & 0.5 & $<0.1-7.8$ \\
\hline & $\mathrm{P}$ & 13 & 1.4 & 1.0 & $0.1-4.2$ \\
\hline \multirow[t]{2}{*}{ Factory 4} & A & 15 & 5.5 & 2.1 & $<0.1-35$ \\
\hline & $\mathrm{P}$ & 11 & 5.6 & 1.8 & $<0.1-38$ \\
\hline \multicolumn{6}{|c|}{ Protease $\left(\mathrm{ng} / \mathrm{m}^{3}\right)$} \\
\hline \multirow[t]{2}{*}{ Factory 1} & A & 22 & 5.8 & 2.3 & $<6.6-23$ \\
\hline & $\mathrm{P}$ & 8 & 170 & 40 & $<50-750$ \\
\hline \multirow[t]{2}{*}{ Factory 2} & A & 19 & 160 & 2.5 & $<5.0-2900$ \\
\hline & $\mathrm{P}$ & 11 & 220 & 170 & $<60-1300$ \\
\hline \multirow[t]{2}{*}{ Factory 3} & A & 17 & 18 & 3.3 & $<30-140$ \\
\hline & $\mathrm{P}$ & 6 & 80 & 25 & $<60-360$ \\
\hline \multirow[t]{2}{*}{ Factory 4} & A & 4 & 13 & 5.5 & $<4.0-40$ \\
\hline & $\mathrm{P}$ & 8 & 360 & 95 & $<60-2200$ \\
\hline \multicolumn{6}{|c|}{ Xylanase $\left(\mathrm{ng} / \mathrm{m}^{3}\right)$} \\
\hline Factory 1 & A & 5 & 6.0 & 6.3 & $2.4-8.0$ \\
\hline Factory 2 & A & 4 & 6.6 & 6.7 & $<0.8-13$ \\
\hline Factory 3 & A & 6 & 3.1 & 2.2 & $<0.8-7.7$ \\
\hline Factory 4 & A & 3 & 5.5 & 0.4 & $<0.8-16$ \\
\hline
\end{tabular}


Table 6 Concentrations of a-amylase in area samples with values above the detection limit in the animal feed industry

\begin{tabular}{llcc}
\hline & Sampling area & $\begin{array}{c}\text { Concentration of } \\
\text { a-amylase }\left(\mathrm{ng} / \mathrm{m}^{3}\right)\end{array}$ & $\begin{array}{c}\text { Corresponding concentration } \\
\text { of total dust }\left(\mathrm{mg} / \mathrm{m}^{3}\right)\end{array}$ \\
\hline Factory 1 & Loading of feed & 20 & 2.5 \\
Factory 2 & Bagging & 90 & 1.7 \\
Factory 3 & Next to enzyme doser & 50 & 0.6 \\
Factory 3 & Next to enzyme doser & 30 & 1.1 \\
Factory 3 & Process & 200 & 7.8 \\
Factory 3 & Process & 200 & 4.5 \\
Factory 4 & Bagging & 20 & 2.5 \\
Factory 4 & Bagging (big sacks) & 70 & 18 \\
\hline
\end{tabular}

$\mathrm{mg} / \mathrm{m}^{3}$ in area samples, and again, protease was below the detection limit.

$\alpha$-Amylase concentration was up to 200 $\mathrm{ng} / \mathrm{m}^{3}$ in area samples. In bagging, total dust values of $0.3-2.1 \mathrm{mg} / \mathrm{m}^{3}$ in personal samples and $0.2-4.2 \mathrm{mg} / \mathrm{m}^{3}$ in area samples were found, whereas protease was under the detection limit. The highest values of $\alpha$-amylase were $20-90$ $\mathrm{ng} / \mathrm{m}^{3}$.

The xylanase concentrations were obtained from the 18 samples collected in different parts of the process. The mean values as well as the maximum concentrations found from the four factories had a narrow range, from less than one to $16 \mathrm{ng} / \mathrm{m}^{3}$. The highest values were measured mainly in parts of the process other than in the vicinity of the enzyme adding machines: in granulation, in mixing, and in bagging of the premixes (no added enzyme) to large sacks. One of the highest values was measured on top of the additive silos that had enzyme premixes in them.

\section{Discussion}

We investigated the prevalence of allergy to enzyme in one of the new areas of enzyme applications. Enzymes have been used since the mid-1980s, and for about the first 5-10 years were premixes in powder form. Liquid preparations started to be used in the mid-1990s, a few months before the study. Because of the cross sectional study design, the study population represented a survivor population. The selection bias would be likely to dilute the findings of any occupational allergy.

Sensitisation to enzymes in the four animal feed factories was found in $7 \%$ of the 140 process workers. By comparison, we found a prevalence of sensitisation of $22 \%$ in 40 exposed process workers in a detergent factory, ${ }^{10}$ and $20.6 \%$ in a group of workers "often exposed" and $11.8 \%$ of workers "occasionally exposed" in two enzyme producing plants. ${ }^{6} \mathrm{~A}$ Danish study showed that $36 \%$ of employees in enzyme production had a RAST value above the detection limit of 0.5 sorbent units (SU) and $8.8 \%$ developed clinical enzyme allergy. ${ }^{12}$ Recent reports from the baking industry show prevalences of $13 \%-16 \%$ of sensitisation to $\alpha$-amylase in the medium exposure category and prevalences of $15 \%-30 \%$ in the high exposure category. ${ }^{413}$ Exposure-response relations for enzyme allergy have been proved previously in baking industry and enzyme production. ${ }^{4}{ }^{13}$ In our study, exposure-response comparisons were not done, as separation of different subcategories of process worker was not practicable, because the tasks vary from time to time.
The sensitised people represent typical workers to be exposed: those handling enzyme premixes themselves and those exposed in other activities during the process. It is noteworthy that one maintenance man had been sensitised; he represents a group which in general is exposed to high dust concentrations in urgent repairs of process disturbances.

The sensitisation to enzymes most probably dates back to the time of using dry enzyme premix preparations, as liquid enzymes were started to be used only recently. It was not possible to estimate enzyme concentrations to which the employees had been exposed at that time. The measurements performed now show the present situation when exposure to airborne enzymes is probably less than before. The data show a great variation in exposure to total dust, and at some sites and tasks high exposure to dust was obvious - such as receiving grain, loading feed, and in maintenance work. Exposure to enzymes does not uniformly follow exposure to total dust: added enzymes are not present in the grain when it is received, and their concentration is low in the end product. Between these stages, exposure to enzymes is possible in the adding of premixes and other process phases. The protease values seemed to coincide with the high total dust concentrations, irrespective of the presence of added enzymes. The measuring method for both $\alpha$-amylase and protease is based on the enzyme activity. Thus, only active enzyme is measured, omitting inactive but potentially sensitising enzyme proteins. Secondly, the method is not specific for the origin of the enzyme activity, as would be an immunological assay; as well as added microbial enzymes, it may detect proteolytic activity of the grain dust. We expect this to be the explanation of the high protease concentrations found.

Atopy was overrepresented among those sensitised to enzymes $(60 \%)$, which accords with most reports on enzyme sensitisation. However, exposed non-atopic workers were also at risk. Consequently, in preventing sensitisation and clinical allergy, the focus has to be at controlling exposure, informing the workers, and monitoring their health.

Sensitisation to storage mites has been shown to be partly due to cross reacting allergens with house dust mite, but specific sensitisation to storage mites also occurs. ${ }^{14}{ }^{15}$ In our study, sensitisation to storage mites only, without sensitisation to house dust mites, was more prevalent in the process group (10 people) than in the office group (one person). In the statistical analyses, both atopy and process work were associated with storage mite sensitisation. Positivity to RAST was more prevalent in process workers. The results suggest that part of the sensitisation to storage mites was of occupational origin.

Sensitisation to flours was more common among the office group than among the process group, whereas most positive RAST tests were among the process group. Here the division into the two groups did not reflect the real exposure differences, as, for example, three of the salesmen seemed to be part time farmers. 
Sensitisation to timothy grass pollen may also explain some of the flour reactions: five of the eight in the office group were skin prick test positive to timothy, whereas, two of the seven people in the process group were sensitised to timothy. It has been shown that flours and timothy have cross reacting antigens. ${ }^{16}$

In conclusion, our study shows that enzymes may cause allergies in the animal feed industry, although to a lesser extent than in enzyme production, and the detergent and baking industries. There is a need to assess exposure to enzymes in various phases of the manufacturing processes of animal feed, especially in handling of the enzyme premixes, as well as in handling of the feed in animal husbandry.

We acknowledge the help of Mr Reima Kämppi for environmental sampling, and Ms Riitta Valio and Ms Terttu Mäkelä for allergy testing. The work was supported by grants from the Finnish Work Environment Fund.

1 Flindt MLH. Pulmonary disease due to inhalation of derivatives of bacillus subtilis containing proteolytic derivatives of bacillus subtilis

2 Baur X, Fruhmann G, Haug B, et al. Role of Aspergillus amylase in bakers' asthma. Lancet 1986;i:43

Brisman J. Industrial enzymes. In: The Nordic expert group for criteria documentation of health risks from chemicals. Arbete och Hälsa. Solna, Sweden: Arbetsmiljöinstitutet, 1994:28.

4 Nieuwenhuijsen MJ, Heederik D, Doekes D, et al. Exposure-response relations of $\alpha$-amylase sensitisation in British bakeries and flour mills.Occup Environ Med 1999;56:197-201

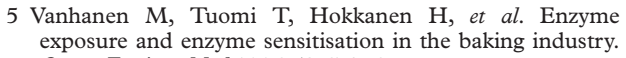
Occup Environ Med 1996;53:670-6.

6 Vanhanen M, Tuomi T, Nordman H, et al. Sensitisation to industrial enzymes in enzyme research and production. Scand 7 Work Environ Health 1997;23:385-91.

7 Doekes G, Kamminga N, Helwegen L, et al. Occupational IgE sensitisation to phytase, a phosphatase derived from Aspergillus niger. Occup Environ Med 1999;56:454-9.

8 Susitaival P, Husman T. Tuohilampi questionnaire. Questions and question-sets designed for epidemiological studies of environmental or work-related symptoms or diseases of respiratory organs, skin and eyes in the adult population. Helsinki: Hakapaino Oy, 1996. (In Finnish.)

9 Ceska M, Eriksson R, Varga JM. Radioimmunosorbent assay of allergens. F Allergy Clin Immunol 1972;49:1-9.

10 Jauhiainen A, Louhelainen K, Linnainmaa M. Exposure to dust and $\alpha$-amylase in bakeries. Appl Occup Environ Hyg 1993;8:721-5.

11 Vanhanen M, Tuomi T, Tiikkainen U, et al. The risk of enzyme allergy in the detergent industry. Occup Environ Med 2000;57:121-5.

12 Johnsen CR, Sorensen TB, Larsen AI, et al. Allergy risk in an enzyme producing plant: a retrospective follow up study. Occup Environ Med 1997;54:671-5.

13 Houba R, Heederik D, Doekes G, et al. Exposuresensitisation relationship for $\alpha$-amylase allergens in the baking industry. Am f Respir Crit Care Med 1996;154:1306.

14 Tee RD. Allergy to storage mites. Clin Exp Allergy 1994;24: 636-40.

15 van der Heide $\mathrm{S}$, Niemeijer NR, Hovenga $\mathrm{H}$, et al. Prevalence of sensitization to the storage mites Acarus siro, Tyrophagus putrescentiae, and Lepidoglyphus destructor in allergic patients with different degrees of sensitization to in allergic patients with different degrees of sensitization to Allergy 1998;53:426-30.

16 Sander I, Raulf-Heimsoth M, Düser M, et al. Differentiation between cosensitization and cross-reactivity in wheat flour and grass pollen-sensitized subjects. Int Arch Allergy Immunol 1997;112:378-85.

\section{Rejected manuscripts}

Authors whose submitted articles are rejected will be advised of the decision and one copy of the article, together with any reviewer's comments, will be returned to them. The
Fournal will destroy remaining copies of the article but correspondence and reviewers' comments will be kept. 